\title{
Predictors of moral harassment in nursing work in critical care units
}

\author{
Preditores do assédio moral no trabalho da enfermagem em unidades de cuidados críticos \\ Predictores del acoso moral en el trabajo en enfermería en unidades de cuidados críticos
}

$\begin{array}{r}\text { Luana Silva de Sousa' } \\ \text { ORCID: 0000-0002-6203-0024 } \\ \text { Roberta Meneses Oliveira"' } \\ \text { ORCID: 0000-0002-5803-8605 } \\ \text { Jênifa Cavalcante dos Santos Santiago" } \\ \text { ORCID: 0000-0001-9815-8698 } \\ \text { Érika da Silva Bandeira' } \\ \text { ORCID: 0000-0002-9421-1903 } \\ \text { Yane Carmem Ferreira Brito' } \\ \text { ORCID: 0000-0003-4362-0296 } \\ \text { Hudson Filipe Arnou Alves' } \\ \text { ORCID: 0000-0002-9407-9332 } \\ \text { Paulo César de Almeida' } \\ \text { ORCID: 0000-0002-2867-802X } \\ \hline\end{array}$

'Universidade Estadual do Ceará. Fortaleza, Ceará, Brazil. "Universidade Federal do Ceará. Fortaleza, Ceará, Brazil.

How to cite this article: Sousa LS, Oliveira RM, Santiago JCS, Bandeira ES, Brito YCF, Alves HFA, et al. Predictors of moral harassment in nursing work in critical care units. Rev Bras Enferm. 2021;74(3):e20200442. https://doi.org/10.1590/0034-7167-2020-0442

Corresponding author: Roberta Meneses Oliveira E-mail: robertameneses@ufc.br

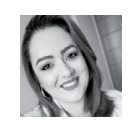

EDITOR IN CHIEF: Antonio José de Almeida Filho ASSOCIATE EDITOR: Marcia Magro

Submission: $08-20-2020$

Approval: 01-18-2021

\section{ABSTRACT}

Objectives: to analyze the predictors of moral harassment in nursing work in critical care units. Methods: a cross-sectional study conducted in a public hospital in Fortaleza, Ceará, with 167 nursing professionals in 2016. Sociodemographic/occupational questionnaire and Negative Acts Questionnaire Revised were applied. The analysis included descriptive statistics, measures of central tendency and dispersion, as well as Mann-Whitney, Kruskal-Wallis and Conover Inman U-tests for multiple comparisons. Results: there was a 33\% prevalence of self-perception of moral harassment, highlighting personal/professional disqualification and work-related harassment. The predictors of moral harassment included age, time working in the job and time in the unit, employment relationship and sector. Conclusions: young professionals ( $<30$ years), cooperative, crowded in intensive care or emergency units, with less time working in the job ( $<5$ years) or greater time in the unit (above 10 years) are the biggest victims of moral harassment in the work of nursing in critical environments. Descriptors: Nursing; Work; Non-Sexual Harassment; Incivility; Critical Care.

\section{RESUMO}

Objetivos: analisar os preditores de assédio moral no trabalho da enfermagem em unidades de cuidados críticos. Métodos: estudo transversal realizado em hospital público de Fortaleza, Ceará, com 167 profissionais de enfermagem, em 2016. Aplicou-se questionário sociodemográfico/ ocupacional e Questionário de Atos Negativos-Revisado. A análise incluiu estatística descritiva, medidas de tendência central e dispersão, bem como testes $U$ de Mann-Whitney, Kruskal-Wallis e ConoverInman para comparações múltiplas. Resultados: encontrou-se prevalência de 33\% para autopercepção de assédio moral, destacando-se desqualificação pessoal/profissional e assédio relacionado ao trabalho. Os preditores do assédio moral incluíram idade, tempo de formação e de atuação na unidade, vínculo empregatício e setor. Conclusões: profissionais jovens ( $<30$ anos), cooperados, lotados em unidades de terapia intensiva ou emergência, com menor tempo de formação ( $<5$ anos) ou maior tempo de atuação da unidade (acima de 10 anos) são as maiores vítimas de assédio moral no trabalho da enfermagem em ambientes críticos.

Descritores: Enfermagem; Trabalho; Assédio Não Sexual; Incivilidade; Cuidados Críticos.

\section{RESUMEN}

Objetivos: analizar los predictores de acoso moral en el trabajo en enfermería en unidades de cuidados críticos. Métodos: estudio transversal realizado en hospital público de Fortaleza, Ceará, con 167 profesionales de enfermería, en 2016. Aplicó encuesta sociodemográfica/ ocupacional y Encuesta de Actos Negativos-Revisado. Análisis incluyó estadística descriptiva medidas de tendencia central y dispersión, así como testes $U$ de Mann-Whitney, Kruskal-Wallis y ConoverInman para comparaciones múltiples. Resultados: encontró prevalencia de 33\% para autopercepción de acoso moral, destacándose descalificación personal/profesional y acoso relacionado al trabajo. Los predictores del acoso moral incluyeron edad, tiempo de formación y de actuación, vínculo laboral y sector. Conclusiones: profesionales jóvenes (< 30 años), cooperados, destinados en unidades de terapia intensiva o emergencia, con menor tiempo de formación ( $<5$ años) o mayor tiempo de actuación de la unidad (arriba de 10 años) son las mayores víctimas de acoso moral en el trabajo de la enfermería en ambientes críticos. Descriptores: Enfermería; Trabajo; Acoso no Sexual; Incivilidad; Cuidados Críticos. 


\section{INTRODUCTION}

Around the world, the working context of nursing and its unfolding in the team's results have been the subject of investigation in different scenarios. A greater emphasis is directed to the study of disruptive behaviors in healthcare work, which are common, measurable and associated with the culture of safety and professional welfare ${ }^{(1-4)}$.

Disruptive behaviors in healthcare work involve incivility and psychological violence, in addition to physical or sexual violence ${ }^{(2,5)}$; and, many times, are treated as synonyms of bullying at work. Researchers reviewed the attributes of this phenomenon in nursing and found characteristic behaviors of incivility, psychological aggression and moral harassment ${ }^{(6-7)}$.

Specifically, moral harassment is any abusive conduct, performed with words, acts or behaviors that may damage the physical or psychic integrity of the worker. In this aggression, the harasser uses the weak points of the victim and makes him/her doubt himself/ herself, aiming at annihilating his/her defenses and, in such a way, progressively shaking his/her self-confidence ${ }^{(8)}$.

It is, therefore, a phenomenon that has been present for many years in nursing work environments and that has plagued the health of professionals worldwide, often veiled or remaining only as an index for situational diagnosis ${ }^{(1,9)}$.

Studies point out the need to investigate this phenomenon better in different practice scenarios, as it directly affects patient care. This happens because the harassed professionals feel incompetent and incapable of carrying out their work, leading to a higher risk of errors and adverse events, because they become unable to think clearly or to concentrate ${ }^{(1,10-11)}$.

Despite the real and complex situation of moral harassment in the hospital environment, studies on this phenomenon in nursing should diversify the public and the places of performance, which contributes to the expansion of knowledge about this problem in different circumstances ${ }^{(7)}$.

In this perspective, although international evidence indicates a higher frequency of moral harassment in critical or high stress units, such as intensive care, operating room and emergency ${ }^{(12-13)}$, there is still no concrete evidence on the predictors of this type of violence in such practice scenarios in Brazil.

\section{OBJECTIVES}

To analyze the predictors of moral harassment in nursing work in critical care units.

\section{METHODS}

\section{Ethical aspects}

The study respected all formal requirements for research with human beings, with the approval of the Ethics in Research Committee of the hospital chosen as the scenario of the research. All participants read and signed the Free Informed Consent Term, in two copies.

\section{Design, time and place of study}

Cross-sectional study guided by the STROBE tool and developed in a public teaching hospital, located in Fortaleza, Ceará,
Brazil, in 2016. It is a reference institution for the North and Northeast regions of the country, with 525 beds in several units and specialties. It was specifically carried out in intensive care units (ICU), emergency and surgical center, as they are sectors of critical care, where there is greater possibility of evidence of moral harassment according to previous studies ${ }^{(1,12-13)}$.

\section{Population or sample; inclusion and exclusion criteria}

According to data from the hospital, in 2016, approximately 600 workers were part of the nursing team of the emergency units, ICU and operating room, among coop members and public servants. The sample was calculated based on the formula for finite population, considering if sample error of $5 \%$, confidence interval of $95 \%$ and prevalence of $50 \%$. With this, there was an estimated total of 234 participants.

The sample was formed by convenience, being included nursing professionals who met the following criteria: to occupy only a care function and to have, at least, one year of activity in the sector. The professionals who were on vacation or distant in the period of the data collection were excluded. At the end, the total of 167 participants was reached, corresponding to $70 \%$ of the estimated sample.

\section{Study protocol}

Two instruments were used to collect the data: a socio-demographic and occupational questionnaire, elaborated by the authors, contemplating the variables gender, age, time working in the job, time in the unit, post-graduation, number of jobs, weekly workload, sector/unit and type of employment relationship; and the Negative Acts Questionnaire Revised (NAQ-R), adapted and validated in Brazil ${ }^{(14)}$.

The good quality of NAQ-R in determining variables related to bullying is endorsed in several studies ${ }^{(15-17)}$, as it allows the identification of targets and the magnitude of exposure, and may favor the construction of significant intervention programs. It is composed of 22 items, each in the form of behavior, without reference to the term "harassment"; it measures how many times the interviewee, during the last six months, was subjected to a series of negative acts and potentially offensive behaviors; and it differentiates subjects who were harassed from those who were not, using a Likert scale from 1 to 5 ( 1 - never, 2 - from time to time, 3 - monthly, 4 - weekly, 5 - daily). Cases of harassment are those in which professionals have experienced or have experienced at least one negative act per week in the past six months ${ }^{(14)}$.

It is divided into four factors: Factor 1 -Work-Related Harassment: the person suffers pressure, negative criticism and boycotts, in such a way that his/her performance is impaired at work; Factor 2 - Personal Harassment: the person feels attacked by hostile behavior and exclusion; Factor 3 - Personal and professional disqualification: the person feels that both his/her work and opinion are not taken into account; and Factor 4 - Physical Intimidation: the person finds himself/herself involved in a situation of physical intimidation or even is a victim of physical violence ${ }^{(14)}$.

The instruments were distributed to nursing professionals in the different shifts (morning, afternoon and night), in a closed envelope and with a deadline of one week for return, without participant identification. 


\section{Statistical analysis of results}

The data was processed in the Statistical Package for the Social Sciences (SPSS) version 20.0, license number 10101131007.

The continuous quantitative variables were analyzed for the mean and standard deviation (SD); and the qualitative variables for the simple and percentage frequency. For the comparison between the means of the scale factors according to the predictor variables (demographic and occupational), it was initially verified the normality of the distribution of the variables through the Kolmogorov Smirnov test, finding a non-normal distribution $(p<0.05)$. Then, the non-parametric tests $U$ of Mann-Whitney (for variables with two categories) and Kruskal-Wallis (for variables with more than two categories) were applied, and multiple comparisons were made by the Conover Inman test. For all analyses, $\mathrm{p}<0.05$ was fixed.

\section{RESULTS}

Participated in the study, 167 nursing professionals, with average age of 37.2 years (Min. $=19 ;$ Max. $=74, S D=11.3$ years), most female $(146 ; 87.4 \%)$, with only one job $(114 ; 61.3 \%)$, assisted in its majority $(131 ; 78.4 \%)$, working in the units of operating room (75; $44.9 \%)$; emergency $(62 ; 37.1 \%)$ and ICU $(30 ; 17.9 \%)$. The averages of time working in the job and time in the unit were 10.2 years (Min. = 1; Max. = 40, SD = 9.4 years) and 7.2 years (Min. = 1; Max. $=40, \mathrm{SD}=8.7$ years), respectively.

Table 1 - Distribution of means and standard deviations of the participants' responses and their comparisons according to the Negative Acts Questionnaire, Fortaleza, Ceará, Brazil, 2016, (N=167)

\begin{tabular}{lcc}
\hline Factor & $\begin{array}{c}\text { Mean } \\
(\mathbf{\pm S D *})\end{array}$ & $\begin{array}{c}\text { Conover-In- } \\
\text { man's } \boldsymbol{p} \leq \mathbf{0 . 0 5} \text { *** }^{*}\end{array}$ \\
\hline F1. Work-related harassment & $1.73( \pm 0.66)$ & $\mathrm{F} 1>\mathrm{F} 2 \mathrm{e}>\mathrm{F} 4$ \\
F2. Personal harassment & $1.47( \pm 0.58)$ & $\mathrm{F} 2<\mathrm{F} 3>\mathrm{F} 4 \mathrm{e}$ \\
F3. Personal and professional disqualification & $1.76( \pm 0.82)$ & $<$ Total Scale \\
F4. Physical intimidation & $1.25( \pm 0.54)$ & $\mathrm{F} 3>\mathrm{F} 4$ \\
Total Scale & $1.59( \pm 0.55)$ & F4 $<$ Total Scale \\
\hline Note: ${ }^{*}$ SD - standard deviation; ${ }^{* *}$ K Kruskal-Wallis test $<0.0001$. &
\end{tabular}

With the application of NAQ-R, it was found that $33 \%$ of the participants reported being harassed at work, and 3.0\% felt harassed several times a week or almost daily. Table 1 gathers the averages of the NAQ-R factors and its general average.

It is noted that the highest averages make up Factors 3 (Personal and Professional Disqualification) and 1 (Work-Related Harassment), respectively, and these are pointed out as the most common forms of moral harassment perceived among study participants.

As for the mean comparison test, it was found that all showed significant differences between them $(p=0.000)$.

Table 2 shows the frequency of professionals who reported weekly or daily harassment in each item of the NAQ-R.

The most mentioned forms of harassment involved: being forced to perform activities at a level below professional capacity (16.2\%), receiving excessive monitoring of work (15.6\%), being pressured not to claim rights (13.2\%), receiving tasks with impossible or irrational goals or deadlines (11.4\%) and having gossip or rumors spread about the professional (11.4\%).

Table 3 shows comparisons of the averages of the predictor variables and of the NAQ-R factors.

The following predictors were associated with moral harassment: age group, time working in the job, time in the unit, type of employment relationship and sector. As for age, there was a significant statistical difference in the averages for Factors 1, 2 and 3, demonstrating that younger professionals (up to 30 years of age) are more likely to be targeted by work-related harassment, personal harassment and personal and professional disqualification than older professionals. In the same way, professionals with less time working in the job (up to 4 years) were more harassed than those trained longer ago. As for the time spent working in the unit, those with 11 to 20 years of service had a higher average than those with less time in the work sector. Finally, the type of unit also showed significant association with moral harassment, being this more experienced in the emergency services and ICU. It also draws attention to the cooperative members (professionals on temporary contracts) being more victims of work-related harassment (Factor 1) than public servants, to the detriment of personal harassment (Factor 2), more referred to by the latter.

Table 2 - Distribution of frequency of responses to items in the Negative Acts Questionnaire Revised according to the moral harassment identified weekly or daily, Fortaleza, Ceará, Brazil, 2016, (N = 167)

\begin{tabular}{|c|c|c|c|}
\hline \multirow{2}{*}{\multicolumn{2}{|c|}{ Factor/Assertive }} & \multicolumn{2}{|c|}{ Harassment } \\
\hline & & No (\%) & Yes (\%) \\
\hline \multicolumn{4}{|c|}{ Factor 1 - Work-related harassment } \\
\hline 5 & Gossip or rumors have been spread about you. & $148(88.6)$ & $19(11.4)$ \\
\hline 10 & You've received tips or signals from others that you should give up your job. & $155(92.8)$ & $12(7.2)$ \\
\hline 11 & You have received reminders of mistakes or mistakes made. & $164(98.2)$ & $3(1.8)$ \\
\hline 16 & You have received tasks with impossible or irrational goals or deadlines. & $148(88.6)$ & $19(11.4)$ \\
\hline 17 & Claims were made against you. & $161(96.4)$ & $6(3.6)$ \\
\hline 18 & Excessive monitoring of your work is done. & $141(84.4)$ & $26(15.6)$ \\
\hline 19 & You have received pressure not to claim your rights. & $145(86.8)$ & $22(13.2)$ \\
\hline 21 & You have been exposed to an unmanageable workload. & $153(91.6)$ & $14(8.4)$ \\
\hline \multicolumn{4}{|c|}{ Factor 2 - Personal harassment } \\
\hline 2 & You have been humiliated or ridiculed because of your work. & $160(95.8)$ & $7(4.2)$ \\
\hline 6 & You have been ignored, excluded or isolated from the group. & $162(97.0)$ & $5(3.0)$ \\
\hline 7 & You have received offensive comments about yourself. & $157(94.0)$ & $10(6.0)$ \\
\hline 8 & You have been cursed or angered for no reason (or fury). & $155(92.8)$ & $12(7.2)$ \\
\hline 12 & You were ignored or faced hostile reaction as you approached. & $165(98.8)$ & $2(1.2)$ \\
\hline 13 & You have received persistent criticism regarding your work and effort. & $159(95.2)$ & $8(4.8)$ \\
\hline 15 & Disrespectful jokes were made by people with whom you are not very close. & $159(95.2)$ & $8(4.8)$ \\
\hline
\end{tabular}




\begin{tabular}{|c|c|c|}
\hline \multirow{2}{*}{ Factor/Assertive } & \multicolumn{2}{|c|}{ Harassment } \\
\hline & No (\%) & Yes (\%) \\
\hline \multicolumn{3}{|l|}{ Factor 3 - Personal and professional disqualification } \\
\hline 1 Someone withheld information that interfered with their performance. & $152(91.0)$ & $15(9.0)$ \\
\hline 3 You have been obliged to perform activities at a level below your capacity. & $140(83.8)$ & $27(16.2)$ \\
\hline 4 Its main areas of responsibility have been replaced by trivial or unpleasant activities. & $152(91.0)$ & $15(9.0)$ \\
\hline 14 Your opinions and points of view were ignored. & $155(92.8)$ & $12(7.2)$ \\
\hline \multicolumn{3}{|l|}{ Factor 4 - Physical intimidation } \\
\hline $\begin{array}{l}9 \text { You have suffered intimidating behavior, such as being pointed with your finger, invading your } \\
\text { personal space, pushed, having your path blocked or barred. }\end{array}$ & $161(96.4)$ & $6(3.6)$ \\
\hline 20 You were the object of sarcasm and excessive provocation. & $164(98.2)$ & $3(1.8)$ \\
\hline 22 You have received threats of violence or physical abuse or real abuse. & $163(97.6)$ & $4(2.4)$ \\
\hline
\end{tabular}

Table 3 - Distribution and comparison of the means of responses according to the categories of socio-demographic/occupational variables and the factors of the Negative Act Questionnaire, Fortaleza, Ceará, Brazil, 2016, ( $N=167)$

\begin{tabular}{|c|c|c|c|c|c|}
\hline Variables & $\begin{array}{l}\text { Work-related } \\
\text { harassment }\end{array}$ & $\begin{array}{c}\text { Personal } \\
\text { harassment }\end{array}$ & $\begin{array}{l}\text { Personal and professional } \\
\text { disqualification }\end{array}$ & $\begin{array}{c}\text { Physical } \\
\text { intimidation }\end{array}$ & $\begin{array}{l}\text { General } \\
\text { score }\end{array}$ \\
\hline \multicolumn{6}{|l|}{ Sex } \\
\hline Male & 1.73 & 1.51 & 1.71 & 1.31 & 1.60 \\
\hline Female & 1.73 & 1.47 & 1.77 & 1.24 & 1.59 \\
\hline$p$ value* & 0.975 & 0.839 & 0.751 & 0.715 & 0.871 \\
\hline \multicolumn{6}{|l|}{ Age group (years) } \\
\hline 19 to 30 & 1.90 & 1.43 & 1.93 & 1.28 & 1.67 \\
\hline 31 to 59 & 1.67 & 1.51 & 1.69 & 1.25 & 1.57 \\
\hline$\geq 60$ & 1.05 & 1.00 & 1.45 & 1.00 & 1.10 \\
\hline$p$ value* & 0.001 & 0.005 & 0.065 & 0.268 & 0.008 \\
\hline \multicolumn{6}{|c|}{ Time working in the job (year) } \\
\hline 1 to 4 & 1.91 & 1.48 & 1.94 & 1.32 & 1.70 \\
\hline 5 to 10 & 1.69 & 1.42 & 1.73 & 1.17 & 1.54 \\
\hline 11 to 20 & 1.77 & 1.70 & 1.70 & 1.37 & 1.68 \\
\hline$\geq 21$ & 1.30 & 1.29 & 1.50 & 1.12 & 1.31 \\
\hline$p$ value* & 0.001 & 0.049 & 0.047 & 0.553 & 0.004 \\
\hline \multicolumn{6}{|c|}{ Time working in the unit (year) } \\
\hline 1 to 4 & 1.83 & 1.46 & 1.85 & 1.24 & 1.63 \\
\hline 5 to 10 & 1.65 & 1.51 & 1.72 & 1.25 & 1.56 \\
\hline 11 to 20 & 1.86 & 1.85 & 1.82 & 1.53 & 1.81 \\
\hline$\geq 21$ & 1.25 & 1.16 & 1.38 & 1.11 & 1.23 \\
\hline$p$ value* & 0.001 & $<0.0001$ & 0.100 & 0.574 & 0.001 \\
\hline \multicolumn{6}{|l|}{ Weekly workload } \\
\hline$<20$ & 2.17 & 1.60 & 2.30 & 2.13 & 2.00 \\
\hline 20 to 40 & 1.66 & 1.43 & 1.69 & 1.19 & 1.53 \\
\hline$>40$ & 1.78 & 1.51 & 1.83 & 1.27 & 1.63 \\
\hline$p$ value* & 0.276 & 0.782 & 0.234 & 0.194 & 0.376 \\
\hline \multicolumn{6}{|c|}{ Type of employment relationship } \\
\hline Cooperated & 1.74 & 1.43 & 1.78 & 1.23 & 1.58 \\
\hline Public servant & 1.56 & 1.54 & 1.67 & 1.16 & 1.52 \\
\hline$p$ value $^{*}$ & 0.010 & 0.044 & 0.738 & 0.075 & 0.069 \\
\hline \multicolumn{6}{|l|}{ Sector } \\
\hline Emergency & 1.86 & 1.46 & 1.85 & 1.32 & 1.66 \\
\hline Operating room & 1.52 & 1.37 & 1.54 & 1.16 & 1.43 \\
\hline $\mathrm{ICU}$ & 1.92 & 1.71 & 2.06 & 1.35 & 1.80 \\
\hline$p$ value* & $<0.0001$ & 0.016 & 0.005 & 0.021 & $<0.0001$ \\
\hline
\end{tabular}

Note: *Value of p: significance of Mann Whitney's U tests for comparison of two samples; and Kruskal Wallis for more than two samples.

\section{DISCUSSION}

The profile of the participants is similar to that already described in other researches carried out with nursing professionals in different clinical contexts. In general, female workers, younger and with little time of service feel more harassed ${ }^{(15,18-20)}$.

Regarding the employment relationship, the fact that more than half of the sample works through cooperatives reflects the problem of precarious ways of working in Brazilian health services. This has the consequence of the lack of job security and the compromising of work relations and patient safety ${ }^{(21)}$.

As for the employment relationship, the fact that more than half of the sample works through cooperatives reflects the problem of precarious ways of working in Brazilian health services. This has the consequence of the lack of job security and the compromise of work relationships and patient safety.

It is important to emphasize that the dimensions of the precariousness of nursing work involve working conditions, the intensity of organization of the work process and the management of this process. In the latter, the existence of conflicts, embarrassment, 
discrimination and workplace violence are discussed. This happens in a context that points out omissions of public power in the maintenance of health services, such as: bad remuneration, absence of public contests and increase of outsourcing of labor force ${ }^{(22)}$.

Considering the results of the application of NAQ-R (Table 1 ), the predominant forms of moral harassment (personal and professional disqualification and work-related harassment) show the most characteristic behaviors of this phenomenon in critical units, as already observed in other studies: professionals suffering pressure, negative criticism, in such a way that their performance is impaired at work; and, moreover, feeling that both their work and their opinion are not taken into account ${ }^{(2,8,10,15-16)}$.

Researchers emphasize the clear prevalence of descending moral harassment types among nurses and nursing technicians, being common the humiliations, embarrassment and persecutions in a repetitive way in the work environment, which destabilize the physical and, mainly, emotional balance of the victim, besides altering the relationship with co-workers and with other individuals ${ }^{(8)}$.

The perpetrators of moral harassment are often professionals with more time on the job, job stability and recognized experience. In general, they adopt attitudes such as delegating excessive activities to subordinates, acting rudely, using abusive language, throwing objects or instruments towards others, generating gossip or conflicts among team members, demonstrating discriminatory attitudes, retaining information about patients or institutional decisions to harm others, to threaten, among other disruptive behaviors ${ }^{(2)}$. The impact on the time offered to direct nursing care is remarkable, harming the patient, who has no involvement with the situation involving the professionals.

Regarding the abuse of power, the pressure of leadership and the ambiguity of roles, it must be considered that such rigid and traditional hierarchical structures, associated with the indetermination of work processes, favor the emergence of increasingly authoritarian nurses and managers with little or no recognition and appreciation by workers and team members ${ }^{(2)}$.

Another example of psychological aggression perceived in health work environments concerns gossip, whose negative side constitutes a dark side of interpersonal relationships, with the capacity to produce elitism, exclusion of individuals, personal and institutional defamation, in addition to systemic abuses, negligence and damage to patients. This type of communication is considered a reflection of several organizational problems that are often silenced and unmanaged ${ }^{(23)}$.

In the UK and elsewhere, bullying involves intentional, personal, repeated, humiliating and isolating psychological violence by co-workers. The main perpetrators are nurses in higher positions than those who are bullied and colleagues who are fixed team members. Those who are likely to be bullied are students and new staff( ${ }^{(10)}$, as we also found in this study.

Despite the real evidence of moral harassment in the Nursing practice environment, there is still a wide recognition that, although these mistreatments and disrespects are perceived and named as violence, they are often considered necessary conduct for the work at some times, as part of the exercise of professional authority ${ }^{(24)}$. Therefore, a systemic and responsible approach to these negative acts is necessary, especially on the part of the area's leaders, taking care not to allow them to become impregnated in the organizational culture.

Workplace violence can cause anguish and depression, causing up to $25 \%$ of intimidated people to leave their jobs or profession, in addition to having a direct impact on patient care. The silence together with the lack of attitudes and management by managers and colleagues allow this behavior to continue. Zero tolerance and the treatment of this behavior in a clear and quick way by the managers should be instigated ${ }^{(10)}$.

Thus, it is believed that hostility in the work environment is perceived in a space where inadequate working conditions and low job satisfaction are frequent, which reflects in losses in interpersonal relationships, in conflict resolution, in the communication process and, consequently, on the rise of authoritarian and excluding professionals ${ }^{(25)}$.

Finally, analyzing the predictors of moral harassment identified in this study (Table 3) (young professionals, recent graduates, or those with longer working time in the unit and working in ICU and emergency), it is possible to perceive the magnitude of the impact of such problem on the career and emotional health of these professionals, even leading them to leave the profession.

Systematic review study on the use of NAQ-R to evaluate bullying among nurses corroborates the findings of this study ${ }^{(15)}$. The data indicated that participants reported bullying at prevalence of $17 \%$ to $94 \%$ ( 19 studies), with age, educational level and years of work experience as the most frequently associated variables, confirming the results of this research.

In New Zealand, there was a general prevalence of $38 \%$ of moral harassment at work by 1,759 health professionals (doctors and dentists), measured by NAQ-R (at least one negative act weekly or daily), $37.2 \%$ self-reported and $67.5 \%$ witnessed. There were significant differences in the harassment rates by specialty $(p=0.001)$, with emergency medicine reporting the highest prevalence (47.9\%). Harassment was significantly associated with increased demand for work and less support from colleagues and managers $(p=0.001)$. The consequences were varied, affecting work environments, personal well-being and the subjective quality of patient care ${ }^{(16)}$.

In another study that evaluated the intentions of rotation, as well as the prevalence and frequency of incivility behaviors in the perspective of 170 health professionals, also with the NAQ-R, it was evidenced the exposure to incivility more frequent in the nursing team than among other health professionals. However, no significant correlations were found between exposure to uncivil behavior and selected demographic variables, suggesting that exposure does not depend on age, race, unit type or educational level. These data differ from those found in our study ${ }^{(17)}$.

Moreover, it is important to emphasize that the nursing workers, in comparison to the other health workers, can suffer more moral harassment, independently of age, race, place of performance, time of formation and performance. The history of the category explains this reality and shows a profession that has always experienced internal and external conflicts related to power and authority.

Researching the past of nursing, it is understood that the difference does not accept and the unresolved conflict is what 
most corrupts relationships within the category. The thesis is that the first nurses were oppressed by a dominant patriarchal system, resentful army medical teams and internal struggles for power, payment, influence and resources ${ }^{(26)}$. Such struggles were propagated and perpetuated in the different scenarios of training and performance of nurses over the years, reflecting negatively on their work processes until today.

In Brazil, when investigating practices of intra-team psychological violence, in the relationships between patients, escorts and other professionals with the nursing workers of the public hospital network, a study indicated that they were relatively young, predominantly female and with considerable professional experience. Verbal aggression was the most frequent subtype of psychological violence $(95 \% ; 84)$, followed by moral harassment $(27 \% ; 24)$. The emergency $(51 \% ; 45)$ was the sector of greatest occurrence; patients $(60 \% ; 53)$, the main aggressors; nurses (76\%; 19) suffered more violence, being the majority female, young and little experienced ${ }^{(18)}$. This association was also tested in the present research, having been observed the inversely proportional relationship between training time and being harassed; and directly proportional between experience time and being harassed.

Other researchers have proven most of the intensive care unit nursing staff to be victims and witnesses of moral harassment behavior, with negative repercussions on job satisfaction and performance, and is also the cause of constant employee turnover ${ }^{(27)}$.

In a Brazilian study with 112 nurses who work in Primary Health Care, workplace violence comprised verbal aggression (67\%) and psychological harassment (bullying - 27.1\%). Team leaders (78.3\%) and other health professionals (41.7\%) were perpetrators, besides patients. Occupational violence was not statistically associated with gender, professional experience, experience in Primary Health Care, weekly work schedule or work shift. The authors concluded that occupational violence is highly prevalent among Brazilian nurses working in Primary Health Care and that the lack of safety at the workplace is the main risk factor associated with ${ }^{(20)}$.

At the institutional level, it is necessary to conceive a culture of health and safety through a shared and sustained commitment of employers and employees, in three levels of action, in order to reduce the vulnerability of the work environment. These three levels include primary, secondary and tertiary prevention strategies. Primary prevention involves education and other measures to identify and reduce vulnerabilities in order to prevent the occurrence of workplace violence. Primary prevention initiatives also aim at improving interpersonal and interprofessional relations. Secondary intervention strategies are designed to reduce harm once an incident of workplace violence has begun. Tertiary strategies, on the other hand, aim to reduce the consequences associated with such an event. Although specified for nurses and employers, recommendations may also be relevant to other health care professionals and stakeholders who collaborate to create and maintain a safe and healthy interprofessional work environment ${ }^{(28)}$.

Managers have important roles in mitigating the problem. Aspects that are determinant in the occurrence of the diseases, such as organizational characteristics and the health work process, should be included in the investigations, thus contributing to a greater understanding of violence in health work and to the search for strategies to combat it ${ }^{(5)}$.

Considering the work in ICU and emergency units, these sectors have exhaustive workloads, either due to the need for agility in the care or the critical character of the patients. These are sectors that exploit great technical and scientific capacity of the professional, counting on protocols and, many times, an exacerbated supervision. Still, in face of the imminent needs, systemic problems leap to the eye.

This context is also part of the work of the nurse in the emergency units ${ }^{(29-30)}$. These factors contribute to harassment behaviors, since the dichotomy between need and reality generates great disquiet, dissatisfaction and often retaliatory attitudes.

Failure to address the problem of harassment also limits the contribution that nurses can make to the health service and prevents future nurses from entering or remaining in the profession, as well as harming and belittling countless good people who want to make a difference and care for others ${ }^{(26)}$.

Thus, early identification in the professional practice environment can offer subsidies to health service managers for the development of prevention and control programs of this behavior in health institutions ${ }^{(6)}$. Efforts to combat bullying at work among nurses and staff need to include training in legitimate methods of performance analysis, workshops on how to interact with various co-workers, and examining how nursing teaching practices contribute to the perpetuation of bullying in clinical settings $\mathrm{s}^{(9)}$.

It is known that the positive senses attributed to work favor the confrontation of degrading circumstances originated by moral harassment ${ }^{(31)}$. Therefore, it is necessary to stimulate the construction of healthy relationships among co-workers in critical units, favoring positive and resilient practice environments.

Promoting strategies for coping with moral harassment in Nursing work, which focus on the needs of the institution and the professionals, depends on the cohesion between the workers and the organization as a whole ${ }^{(25)}$.

\section{Study limitations}

Some study limitations were the scope of the total estimated sample and the fear that workers showed in participating, for fear of retaliation from colleagues or management, although it was explained about ensuring anonymity and confidentiality of data. A larger sample could highlight more critical and relevant points for a future intervention.

\section{Contributions to the Nursing, Health or Public Health Area}

Assessing moral harassment in the daily work of the nursing team in critical units encourages nurses, managers, researchers, students and health leaders to learn more about the related factors, the most frequent behaviors and the consequences of this phenomenon for everyone involved. Thus, there are subsidies to plan strategies for permanent education and performance evaluation more directed to the effective management of each case, leading professionals to review their conflict resolution skills, as well as their roles and professional values. 


\section{CONCLUSIONS}

There was a 33\% prevalence of self-perception of moral harassment among nursing professionals in critical care units, $3 \%$ weekly or daily and $30 \%$ rarely or once in a while. The predictors of the moral harassment were age (under 30 years), time working in the job (under 5 years) and time in the unit (more than 10 years), type of employment relationship (cooperative) and work unit (ICU and emergency). Thus, the professionals who most feel morally harassed at work in critical care units are the newly graduated, those with longer working time in the unit, those with temporary contracts (cooperative) and those working in emergency and ICU.

\section{REFERENCES}

1. Pereira CAR, Borgato MH, Colichi RMB, Bocchi SCM. Institutional strategies to prevent violence in nursing work: an integrative review. Rev Bras Enferm. 2019;72(4):1052-60. https://doi.org/10.1590/0034-7167-2018-0687

2. Oliveira RM, Silva LMS, Guedes MVC, Oliveira ACS, Sánchez RG, Torres RAM. Analyzing the concept of disruptive behavior in healthcare work: an integrative review. Rev Esc Enferm USP. 2016;50(4):690-9. https://doi.org/10.1590/s0080-623420160000500021

3. Rehder KJ, Adair KC, Hadley A, McKittrick K, Frankel A, Leonard M, et al. Associations between a new disruptive behaviors scale and teamwork, patient safety, work-life balance, burnout, and depression. Jt Comm J Qual Patient Saf. 2020;46(1):18-26. https://doi.org/10.1016/j.jcjq.2019.09.004

4. Maddineshat $\mathrm{M}$, Rosenstein AH, Akaberi A, Tabatabaeichehr M. Disruptive behaviors in an emergency department: the perspective of physicians and nurses. J Caring Sci. 2016;5(3):241-9. https://doi.org/1015171/jcs.2016.026

5. Moreira FTLS, Callou RCM, Albuquerque GA, Oliveira RM. Effective communication strategies for managing disruptive behaviors and promoting patient safety. Rev Gaúcha Enferm. 2019;40(spe):e20180308. https://doi.org/10.1590/1983-1447.2019.20180308

6. Aoki RN, Guirardello EB. Bullying in the nursing work environment: integrative review. Rev Gaúcha Enferm. 2019;40:e20190176. https://doi. org/10.1590/1983-1447.2019.20190176

7. Lucena PLC, Costa SFG, Batista JBV, Lucena CMF, Morais GSN, Costa BHS. Scientific production on workplace bullying and nursing: a bibliometric study. Rev Esc Enferm USP. 2018;52:e03354. https://doi.org/10.1590/S1980-220X2017029103354

8. Andrade CG, Leão JDM, Costa ICP, Brito FM, Santos KFO, Costa SFG. Assédio moral na atenção básica segundo os profissionais de enfermagem. Trab Educ Saúde. 2015;13(supl1):77-90. https://doi.org/10.1590/1981-7746-sip00031

9. Johnson SL. Workplace bullying, biased behaviors and performance review in the nursing profession: a qualitative study. J Clin Nurs. 2019;28(9-10):1528-37. https://doi.org/10.1111/jocn.14758

10. Wilson J. An exploration of bullying behaviors in nursing: a review of the literature. Br J Nurs. 2016; 25(6):303-6. https://doi.org/10.12968/ bjon.2016.25.6.303

11. Jesus MAC, Souza NVDO, Costa CCP, Carvalho EC, Gallash CH, Souza PHDO. Psychological harassment in the hospital nursing workplace: an integrative literature review. Rev Enferm UERJ. 2016; 24(4):e26437. https://doi.org/10.12957/reuerj.2016.26437

12. Brewer CS, Kovner CT, Obeidat RF, Budin WC. Positive work environments of early-career registered nurses and the correlation with physician verbal abuse. Nurs Outlook. 2013;61(6):408-16. https://doi.org/10.1016/j.outlook.2013.01.004

13. Grogan MJ, Knechtges P. The disruptive physician: a legal perspective. Acad Radiol. 2013;20(9):1069-73. https://doi.org/10.1016/j. acra.2013.04.015

14. Silva IV, Aquino EML, Pinto ICM. Psychometric properties of the Negative Acts Questionnaire for the detection of workplace bullying: an evaluation of the instrument with a sample of state health care workers. Rev Bras Saúde Ocup. 2017;42:e2. https://doi. org/10.1590/2317-6369000128715

15. Serafin L, Sak-Dankosky N, Cazrkowska B. Bullying in nursing evaluated by the Negative Acts Questionnaire-Revised: a systematic review and meta-analysis. J Adv Nurs. 2020;76:1320-33. https://doi.org/10.1111/jan.14331

16. Chambers CNL, Frampton CMA, McKee M, Barclay M. 'It feels like being trapped in an abusive relationship': bullying prevalence and consequences in the New Zealand senior medical workforce: a cross-sectional study. BMJ Open. 2018;8(3):e020158. https://doi.org/10.1136/ bmjopen-2017-020158

17. Evans D. Categorizing the magnitude and frequency of exposure to uncivil behaviors: a new approach for more meaningful interventions. J Nurs Scholarsh. 2017;49(2):214-22. https://doi.org/10.1111/jnu.12275

18. Lima GHA, Sousa SMA. Psychological violence in the nursing work. Rev Bras Enferm. 2015;68(5):535-41. https://doi. org/10.1590/0034-7167.2015680508i

19. Borges EMN, Ferreira TJR. Bullying no trabalho: adaptação do Negative Acts Questionnaire-Revised (NAQ-R) em enfermeiros. Rev Port Enferm Saúde Mental [Internet]. 2015 [cited 2020 Apr 17];13:25-33. Available from: http://www.scielo.mec.pt/pdf/rpesm/n13/n13a04.pdf

20. Cavalcanti AL, Belo EDR, Marcolino EC, Fernandes A, Cavalcanti YW, Carvalho DF, et al. Occupational Violence against Brazilian Nurses. Iran J Public Health [Internet]. 2018 [cited 2020 Apr 19];47(11):1636-43. Available from: https://ijph.tums.ac.ir/index.php/ijph/article/view/15143

21. Oliveira RM, Leitão IMTA, Aguiar LL, Oliveira ACS, Gazos DM, Silva LMS, et al. Evaluating the intervening factors in patient safety: focusing on hospital nursing staff. Rev Esc Enferm USP. 2015;49(1):104-13. https://doi.org/10.1590/S0080-623420150000100014 
22. Araújo-dos-Santos T, Silva-Santos H, Silva MN, Coelho ACC, Pires CGS, Melo CMM. Job insecurity among nurses, nursing technicians and nursing aides in public hospitals. Rev Esc Enferm USP. 2018;52:e03411. https://doi.org/10.1590/S1980-220X2017050503411

23. Waddington K. Rethinking gossip and scandal in healthcare organizations. J Health Organ Manag. 2016;30(6):810-7. https://doi. org/10.1108/jhom-03-2016-0053

24. Shea T, Sheehan C, Donohue R, Cooper B, Cieri H. Occupational violence and aggression experienced by nursing and caring professional. J Nurs Scholarsh. 2017;49(2):236-43. https://doi.org/10.1111/jnu.12272

25. Sousa LS, Alves HFA, Sobral MC, Landim ALP, Leitão IMT, Oliveira RM. Análise do assédio moral no trabalho da enfermagem em unidades críticas: um fenômeno que preocupa [Internet]. In: XX Enfermaio; II SIEPS; I Mostra do Internato em Enfermagem; 2016; Fortaleza, Brasil. Fortaleza: SIEPS. 2016 [citado 2020 mar 14]. Available from: http://uece.br/eventos/iiseminarioppcclisenfermaio/anais/trabalhos_ completos/256-22795-08052016-222203.pdf

26. Stanley D. A brief history of bullying in nursing: battles and bullies. JOJ Nurs Health Care. 2019;11(1):555804. https://doi.org/10.19080/ JOJNHC.2019.11.555804

27. Ruíz-González KJ, Pacheco-Pérez LA, García-Bencomo MI, Gutiérrez Diez MC, Guevara-Valtier MC. Mobbing perception among intensive care unit nurses. Enferm Intensiva. 2019;19:30065-3. https://doi.org/10.1016/j.enfi.2019.03.007

28. American Nurses Association. American nurses association position statement on incivility, bullying, and workplace violence [Internet]. 2015 [cited 2020 Mar 14]. Available from: https://www.nursingworld.org/ 49d6e3/globalassets/practiceandpolicy/nursing-excellence/ incivility-bullying-and-workplace-violence--ana-position-statement.pdf

29. Campo VR, Klijn TP. Verbal abuse and mobbing in pre-hospital care services in Chile. Rev Latino-Am Enfermagem. 2017;25(e2956). https:// doi.org/10.1590/1518-8345.2073.2956

30. Oliveira FP, Mazzaia MC, Marcolan JF. Symptoms of depression and intervening factors among nurses of emergency hospital services. Acta Paul Enferm. 2015;28(3):209-15. https://doi.org/10.1590/1982-0194201500036

31. Lucas MG, Romano R. Assédio moral nas relações de trabalho: implicações psicológicas. ReCaPe. 2016;5(3):392-401. https://doi. org/10.20503/recape.v5i3.21854 